\title{
A Quantitative Structure-Activity Relationship and Molecular Modeling Study on a Series of Biaryl Imidazole Derivatives Acting as $\mathbf{H}^{+} / \mathbf{K}^{+}$-ATPase Inhibitors
}

\author{
Neeraj Agarwal, ${ }^{1}$ Anubha Bajpai, ${ }^{1}$ Vivek Srivastava, ${ }^{1}$ and Satya P. Gupta ${ }^{2}$ \\ ${ }^{1}$ Department of Biotechnology, Meerut Institute of Engineering and Technology, Meerut 250005, India \\ ${ }^{2}$ Department of Pharmaceutical Technology and Department of Applied Sciences, Meerut Institute of Engineering and Technology, \\ Meerut 250005, India \\ Correspondence should be addressed to Satya P. Gupta; spgbits@gmail.com
}

Received 17 September 2012; Revised 23 November 2012; Accepted 26 November 2012

Academic Editor: Shandar Ahmad

Copyright (C) 2013 Neeraj Agarwal et al. This is an open access article distributed under the Creative Commons Attribution License, which permits unrestricted use, distribution, and reproduction in any medium, provided the original work is properly cited.

\begin{abstract}
The $\mathrm{H}^{+} / \mathrm{K}^{+}$-ATPase or proton pump is a magnesium-dependant enzyme which causes the exchange of a proton against a potassium ion through a membrane. Over activity of this enzyme causes hyperacidity by producing more of hydrochloric acid inside the stomach. This enzyme, therefore, has been found to be a good target for designing compounds to treat hyperacidity. A quantitative structure-activity relationship (QSAR) study has been made on a novel series of biaryl imidazole derivatives acting as $\mathrm{H}^{+} / \mathrm{K}^{+}$ATPase inhibitors. The $\mathrm{H}^{+} / \mathrm{K}^{+}$-ATPase inhibition activity of these compounds is found to be significantly correlated with global topological charge indices (GTCIs) and the total polar surface area (TPSA) of the molecules, indicating the involvement of strong electronic interaction between the molecule and the receptor. Based on the correlations obtained, some new $\mathrm{H}^{+} / \mathrm{K}^{+}$-ATPase inhibitors are predicted. The docking studies of these predicted compounds exhibit that these compounds will have even better interaction with the receptor than those already marketed. Thus, they can prove more potent drugs for the treatment of hyperacidity.
\end{abstract}

\section{Introduction}

The hyperactivity of $\mathrm{H}^{+} / \mathrm{K}^{+}$-ATPase, the enzyme located in the parietal cells, is responsible for the final step of acid secretion in the stomach, leading to many acid-related diseases, such as stomach and duodenal ulcers, symptoms of esophagitis (inflammation of esophagus, the tube from the mouth to the stomach), and severe gastroesophageal reflux disease (GERD), a condition where acid leaks up from the stomach into the esophagus. This enzyme is also called proton pump. Since it is unique to parietal cells, it is considered to be a good target for developing the drugs for curing acid-related diseases [2]. The design of proton pump inhibitors (PPIs) is focused on achieving long lasting and rapid inhibition of acid secretion [1]. The PPIs decrease the amount of acid produced in the stomach by inhibiting the function of the pump and are thus useful to treat GERD $[3,4]$. The mechanisms of action of PPIs are focused on the final step of gastric acid secretion which are competitive with respect to $\mathrm{K}^{+}$binding to the parietal cell gastric $\mathrm{H}^{+} / \mathrm{K}^{+}$-ATPase $[3,5,6]$. There are also reversible PPIs that bind near the site of $\mathrm{K}^{+}$channel and inhibit the action of $\mathrm{H}^{+} / \mathrm{K}^{+}$-ATPase $[7,8]$. They are thus also called potassium-competitive acid blockers (P-CABs). The therapeutic action of these $\mathrm{P}-\mathrm{CABs}$ is somewhat superior to that of PPIs in terms of faster mechanism of action and long duration, which result in quicker relief and healing $[2,3,9,10]$. However, the purpose of this paper is to analyze the structure-activity relationship of a series of PPIs and to predict still better compounds based on this study. Currently licensed PPIs are omeprazole, lansoprazole, rabeprazole, and pantoprazole (Figure 1). Out of these, omeprazole was the first PPI to reach the market in 1988, and its properties are well documented [11].

The quantitative structure-activity relationship (QSAR) and molecular modeling studies have been increasingly employed in rational drug discovery process to understand the drug receptor interaction and to design new molecules with higher potency. Some important QSAR 


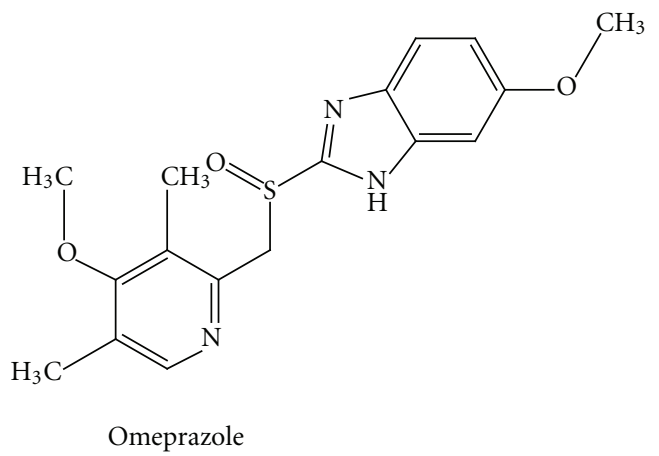<smiles>Cc1c(OC(F)(F)F)ccnc1CS(=O)c1nc2ccccc2[nH]1</smiles><smiles>COCCCOc1ccnc(CS(=O)c2nc3ccccc3[nH]2)c1C</smiles>

Rabeprazole<smiles>COc1ccnc(CS(=O)c2nc3ccc(OC(F)(F)F)cc3[nH]2)c1OC</smiles>

Pantoprazole

FIGURE 1: Licensed compounds available in the market.<smiles>[R]c1ccc(N)c(CS(=O)c2nc3ccccc3[nH]2)c1</smiles>

(1)<smiles>[R]c1cccc(-c2csc(N=C(N)N)n2)c1</smiles>

(4)<smiles>[R1]c1ccc2[nH]c(S(=O)Cc3cccc([R])n3)nc2c1</smiles>

(2)<smiles>[R1][I-]c1cccc(N2CCc3c(C)nc4c([R])cccc4c32)c1</smiles>

(3)<smiles>[R]N/C(N)=N\c1nc(-c2c[nH]c3ccccc23)c([R])s1</smiles>

(5)

SCHEME 1

studies on PPIs have been reported in the past. Ojha and coworkers [12, 13] reported excellent QSAR studies on two different series of analogues of omeprazole itself $(\mathbf{1 , 2}$, Scheme 1). These authors also reported QSARs on a series of 2,3-dihydropyrroloquinolines (3, Scheme 1) [13] and two different series of 2-guanidinothiazoles (4,5, Scheme 1) [14]. In all their QSAR studies, these authors found the significant role of electronic properties of substituents, indicating that the overall electronic properties of molecules may be important for the inhibition of $\mathrm{H}^{+} / \mathrm{K}^{+}$-ATPase. On 
the same two series of 2-guanidinothiazoles $(4,5$, Scheme 1), Borges and Takahata also reported from their two consecutive studies $[15,16]$ that the electronic properties of compounds such as dipole moment and charges at some atoms, are important for their activity. On a fairly large series of $\alpha$-amino acid derivatives, a QSAR study performed by Sharma et al. [17] also suggested that their PPI inhibition activity is controlled by the electronic properties, such as the energy of the highest occupied molecular orbital $\left(E_{\mathrm{HOMO}}\right), \mathrm{H}$-bond formation ability of some groups, and steric factors. A series of 179 quinoline and quinazoline heterocyclic analogues exhibiting inhibitory activity against $\mathrm{H}^{+}, \mathrm{K}^{+}$-ATPase were investigated by comparative molecular field analysis (CoMFA) and comparative molecular similarity indices analysis (CoMSIA) by Nayana et al. [18] to find that in addition to electrostatic and steric fields, hydrophobic and $\mathrm{H}$-bond donor and acceptor fields were also important for the $\mathrm{H}^{+}, \mathrm{K}^{+}$-ATPase inhibition activity of these compounds. In the present paper, we have made a QSAR study on a totally new series of compounds, namely, a series of biaryl imidazoles, acting as PPI inhibitors. So far, nobody has made any QSAR study on these compounds. The main objective of this study is to report the physicochemical properties that govern the activity of these compounds. Using QSAR model, we have reported some new compounds of the series that may have better activity. A docking study has been made of these new compounds and their results have been compared with those of licensed compounds. The ADME/T properties of these compounds have also been studied and checked with the Lipinski rules.

\section{Materials and Methods}

We have taken a series of forty-two molecules of biaryl imidazoles acting as $\mathrm{H}^{+} / \mathrm{K}^{+}$-ATPase inhibitors that were synthesized and evaluated for their antisecretory activity by Garton et al. [1]. All the compounds of this series are listed in Table 1 along with their antisecretory activity. This Table also lists the physicochemical and topological parameters of the compounds that were found to govern their potency. The most significant parameters that were found to govern the activity of the compounds were global topological charge indices (GTCIs) and the total polar surface area (TPSA). Both of these parameters were calculated by E-Dragon version 1.0 [19]. In deriving QSAR model, two indicator parameters, $I_{1}$ and $I_{2}$, have also been used. $I_{1}$ has been used with a value of 1 for the molecules having fused rings such as compounds 1 and 2 in Table 1 , and $I_{2}$ with a value of 1 has been used for the compounds having a bridge group between two aryl rings or having the pendent ring at ortho or para position. $\mathrm{I}_{2}$ is otherwise equal to zero if the two aryl rings are directly connected.

For performing docking studies and to check the interactions between the predicted compounds, the protein has been taken from protein data bank (PDB id 2XZB), and the Mole Grow Virtual Docker software has been used for docking. The ADME/T properties are predicted with the help of Abbreviated Profile of Drugs (APOD) [20], which requires the molecular weight, hydrogen bond donor and hydrogen bond acceptor counts, octanol-water partition coefficient $(\log P)$, polar surface area, and bioavailability (optional) of the molecules, which are calculated with the help of Marvin Sketch. These parameters are used to verify Lipinski's rule.

\section{Results and Discussion}

3.1. QSAR Results. All the compounds of Table 1 were divided into two subsets: training set and test set. Compounds for the test were selected arbitrarily by keeping in mind the wide variation in their structures and a good span in their activity data. All the test set compounds are given with superscript " $b$ " and in bold in Table 1 . The rest of the compounds were taken in the training set. When a multiple regression analysis (Hansch analysis) was performed on the compounds of the training set, it revealed the following correlation.

$$
\begin{aligned}
& \log \left(\frac{1}{\mathrm{IC}_{50}}\right)= 3.581( \pm 3.018) \mathrm{GTCI} \\
&+0.014( \pm 0.008) \mathrm{TPSA} \\
&+1.413( \pm 0.557) \mathrm{I}_{1}-0.573( \pm 0.322) \mathrm{I}_{2} \\
&+2.829, \\
& n=28, \quad r=0.923, \quad r_{\mathrm{cv}}^{2}=0.740, \quad r_{\text {pred }}^{2}=0.742, \\
& s=0.31, \quad F_{4,23}=33.12(4.26) .
\end{aligned}
$$

In (1), $n$ is the number of data points, $r$ is the correlation coefficient, $r_{\mathrm{cv}}^{2}$ is the square of the cross-validated correlation coefficient obtained from leave-one-out (LOO) jackknife procedure, $s$ is the standard deviation, $F$ is the Fischer ratio between the variances of calculated and observed activities, and the data within the parentheses with \pm sign are $95 \%$ confidence intervals. The figure within the parentheses for $F$ is the standard $F$-value at $99 \%$ level. In the activity term $\log \left(1 / \mathrm{IC}_{50}\right), \mathrm{IC}_{50}$ refers to molar concentration of the compound leading to $50 \%$ inhibition of enzyme. The value of these statistical parameters exhibited that the correlation obtained is quite significant. This correlation suggests that the $\mathrm{H}^{+} / \mathrm{K}^{+}$-ATPase inhibition activity of this series of compounds is basically controlled by the global topological charge indices and the total polar surface area of the molecules. Since GTCI describes charge transfer between pairs of atoms and TPSA is indicative of total polar surface area, the correlation indicates the involvement of strong electronic interaction between the molecules and the receptor. This result is very much in tune with the findings of other authors regarding other classes of PPI inhibitors as discussed peviously. The two parameters, GTCI and TPSA, used in (1) have no mutual correlation $(r=0.333)$. No mutual correlations were found to exist among all the parameters. 
TABLE 1: A series of $\mathrm{H}^{+} / \mathrm{K}^{+}$-ATPase inhibitors and their activity.

(a)<smiles>[R]c1cccc(C)c1CNc1cc(C(N)=O)cn2c(C)c(C)nc12</smiles>

(1-2)

\begin{tabular}{lcccccccc}
\hline S. no. & $\mathrm{R}$ & GTCI & TPSA & $\mathrm{I}_{1}$ & $\mathrm{I}_{2}$ & & \multicolumn{2}{c}{$\log \left(1 / \mathrm{IC}_{50}\right)$} \\
& & & & & & Obsd $^{\mathrm{a}}$ & Calcd, (1) & Pred (LOO) \\
\hline 1 & $\mathrm{Et}$ & 0.50 & 72.42 & 1.00 & 0.00 & 7.00 & 7.04 & 7.06 \\
2 & $\mathrm{Me}$ & 0.52 & 72.42 & 1.00 & 0.00 & 7.10 & 7.11 & 7.10 \\
\hline
\end{tabular}

(b)

\begin{tabular}{|c|c|c|c|c|c|c|c|c|c|}
\hline & & & & $\left.\right|_{N} ^{\mathrm{Me}}$ & & & & & \\
\hline \multirow[t]{2}{*}{ S. no. } & \multirow[t]{2}{*}{$\mathrm{X}$} & \multirow[t]{2}{*}{$\mathrm{Ar}^{1}$} & \multirow[t]{2}{*}{ GTCI } & \multirow[t]{2}{*}{ TPSA } & \multirow{2}{*}{$\mathrm{I}_{1}$} & \multirow{2}{*}{$\mathrm{I}_{2}$} & \multicolumn{3}{|c|}{$\log \left(1 / \mathrm{IC}_{50}\right)$} \\
\hline & & & & & & & Obsd $^{\mathrm{a}}$ & Calcd, (1) & Pred (LOO) \\
\hline 3 & - & $\mathrm{Ph}$ & 0.40 & 28.68 & 0.00 & 0.00 & 4.70 & 4.68 & 4.67 \\
\hline 4 & - & 2-Me-Ph & 0.45 & 28.68 & 0.00 & 0.00 & 5.10 & 4.83 & 4.80 \\
\hline 5 & - & 2,6-diMe-Ph & 0.48 & 28.68 & 0.00 & 0.00 & 5.20 & 4.95 & 4.91 \\
\hline 6 & - & 2,6-diEt-Ph & 0.44 & 28.68 & 0.00 & 0.00 & 5.10 & 4.82 & 4.78 \\
\hline $7^{\mathrm{b}}$ & - & 3-Me-triophene-4-yl & 0.45 & 28.68 & 0.00 & 0.00 & 4.80 & 4.85 & - \\
\hline 8 & $\mathrm{NH}$ & 2,6-diMe-Ph & 0.48 & 40.71 & 0.00 & 1.00 & 4.90 & 4.53 & 4.4 \\
\hline 9 & (trans) $\mathrm{CH}=\mathrm{CH}$ & $\mathrm{Ph}$ & 0.38 & 28.68 & 0.00 & 1.00 & 4.40 & 4.03 & 3.87 \\
\hline $10^{\mathrm{b}}$ & $\mathrm{CH}_{2} \mathrm{CH}_{2}$ & $\mathrm{Ph}$ & 0.38 & 28.68 & 0.00 & 1.00 & 4.30 & 4.03 & - \\
\hline 11 & $\mathrm{NHCH}_{2}$ & 2,6-diMe-Ph & 0.47 & 40.71 & 0.00 & 1.00 & 4.30 & 4.57 & $4.55^{\mathrm{b}}$ \\
\hline 12 & CONH & $\mathrm{Ph}$ & 0.42 & 57.78 & 0.00 & 1.00 & 4.00 & 4.58 & 4.72 \\
\hline $13^{\mathrm{b}}$ & Ortho & $\mathrm{Ph}$ & 0.38 & 28.68 & 0.00 & 1.00 & 4.20 & 4.00 & 4.17 \\
\hline 14 & Para & 2,6-diMe- $\mathrm{Ph}$ & 0.50 & 28.68 & 0.00 & 1.00 & 4.40 & 4.40 & 4.43 \\
\hline
\end{tabular}


(c)<smiles>[R][Y]1:[Y]([R])c(-c2cccc(-c3c(C)cccc3C)c2)n([R])c1[R]</smiles>

$(15-22)$<smiles>[M]C1CCN(c2cccc(-c3c(C)cccc3C)c2)CC1</smiles>

(24)<smiles>CNCc1cccc(-c2c(C)cccc2C)c1</smiles>

(25)

$\log \left(1 / \mathrm{IC}_{50}\right)$

$\begin{array}{lllllllllll}\text { S. no. } & \mathrm{X} & \mathrm{Y} & \mathrm{R}^{1} & \mathrm{R}^{2} & \mathrm{R}^{3} & \text { GTCI } & \text { TPSA } & \mathrm{I}_{1} & \mathrm{I}_{2}\end{array}$

Obsd $^{\mathrm{a}}$ Calcd, (1) Pred (LOO)

\begin{tabular}{|c|c|c|c|c|c|c|c|c|c|c|c|c|}
\hline $15^{\mathrm{b}}$ & $\mathrm{N}$ & $\mathrm{C}$ & $\mathrm{H}$ & $\mathrm{H}$ & $\mathrm{H}$ & 0.36 & 28.68 & 0.00 & 0.00 & 4.50 & 4.53 & - \\
\hline 16 & $\mathrm{~N}$ & $\mathrm{C}$ & $\mathrm{H}$ & Et & Et & 0.45 & 26.68 & 0.00 & 0.00 & 4.80 & 4.80 & 4.80 \\
\hline 17 & $\mathrm{~N}$ & $\mathrm{C}$ & $\mathrm{H}$ & $\mathrm{Ph}$ & - & 0.36 & 28.68 & 0.00 & 0.00 & 4.40 & 4.52 & 5.32 \\
\hline $18^{\mathrm{c}}$ & $\mathrm{N}$ & $\mathrm{C}$ & $\mathrm{Me}$ & $\mathrm{H}$ & $\mathrm{H}$ & 0.41 & 17.82 & 0.00 & 0.00 & 5.20 & 4.54 & - \\
\hline $19^{\mathrm{b}}$ & $\mathrm{N}$ & $\mathrm{C}$ & $\mathrm{Me}$ & $\mathrm{Me}$ & $\mathrm{Me}$ & 0.49 & 17.82 & 0.00 & 0.00 & 4.60 & 4.83 & - \\
\hline 20 & $\mathrm{~N}$ & $\mathrm{C}$ & $\mathrm{N}-\mathrm{Pr}$ & $\mathrm{H}$ & $\mathrm{H}$ & 0.39 & 17.82 & 0.00 & 0.00 & 4.30 & 4.46 & 4.48 \\
\hline $21^{\mathrm{b}}$ & $\mathrm{CH}$ & $\mathrm{N}$ & - & $\mathrm{Me}$ & $\mathrm{Me}$ & 0.48 & 17.82 & 0.00 & 0.00 & 4.80 & 4.80 & - \\
\hline 22 & $\mathrm{CH}$ & $\mathrm{N}$ & $\mathrm{n}-\mathrm{Pr}$ & $\mathrm{H}$ & - & 0.41 & 17.82 & 0.00 & 0.00 & 4.40 & 4.54 & 4.55 \\
\hline 23 & - & - & - & - & - & 0.42 & 38.91 & 0.00 & 0.00 & 4.50 & 4.86 & 4.88 \\
\hline 24 & - & - & - & - & - & 0.43 & 6.48 & 0.00 & 0.00 & 4.40 & 4.46 & 4.47 \\
\hline $25^{\mathrm{b}}$ & - & - & - & - & - & 0.42 & 12.03 & 0.00 & 0.00 & 4.30 & 4.50 & - \\
\hline
\end{tabular}

(d)

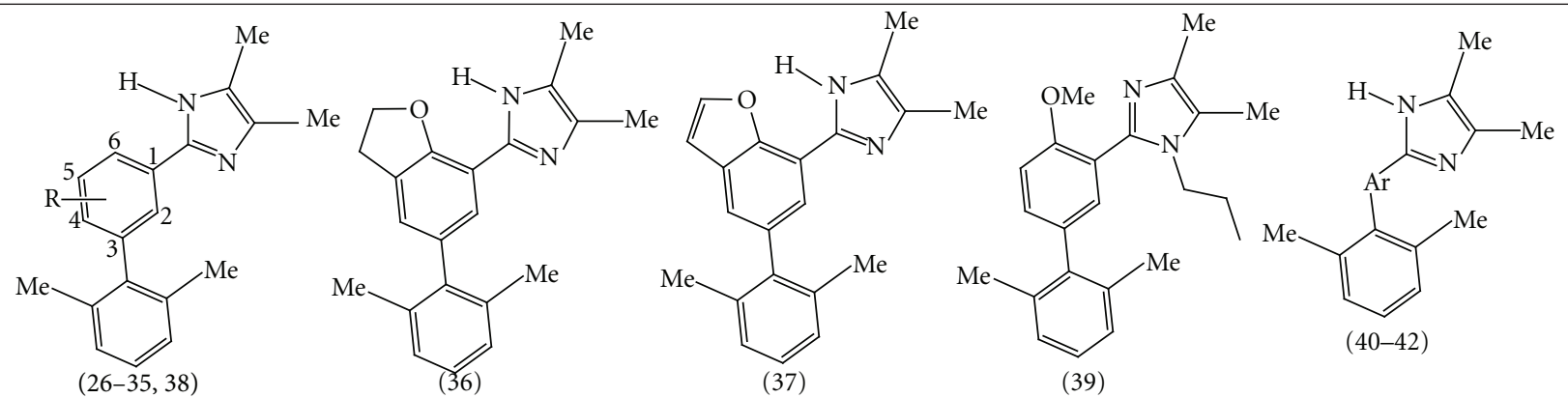

$\begin{array}{lllll}\text { S. no. } & \mathrm{R} & \text { GTCI } & \text { TPSA } & \mathrm{I}_{1}\end{array}$

$\log \left(1 / \mathrm{IC}_{50}\right)$

Obsd $^{\mathrm{a}} \quad$ Calcd, (1)

Pred (LOO)

\begin{tabular}{llllllllll}
$26^{\mathrm{c}}$ & 6-OMe & 0.50 & 37.91 & 0.00 & 0.00 & 6.10 & 5.15 & - \\
27 & $4-\mathrm{OMe}$ & 0.50 & 37.91 & 0.00 & 0.00 & 4.90 & 5.14 & 5.12 \\
\hline
\end{tabular}


(d) Continued.

\begin{tabular}{|c|c|c|c|c|c|c|c|c|}
\hline 28 & 4-Me & 0.51 & 26.68 & 0.00 & 0.00 & 4.90 & 5.04 & 5.04 \\
\hline $29^{c}$ & 5,6-DiMeO & 0.50 & 69.14 & 0.00 & 0.00 & 4.60 & 5.59 & - \\
\hline 30 & $6-\mathrm{OH}$ & 0.52 & 48.91 & 0.00 & 0.00 & 5.70 & 5.37 & 5.28 \\
\hline $31^{\mathrm{b}}$ & 6 -OEt & 0.48 & 37.91 & 0.00 & 0.00 & 5.60 & 5.09 & - \\
\hline 32 & $6-\mathrm{OBn}$ & 0.42 & 37.91 & 0.00 & 0.00 & 5.30 & 4.87 & 4.81 \\
\hline 33 & $6-\mathrm{OBn}$ & 0.52 & 37.91 & 0.00 & 0.00 & 5.00 & 5.20 & 5.20 \\
\hline 34 & $6 \mathrm{OCH}_{2} \mathrm{CO}_{2} \mathrm{Me}$ & 0.49 & 64.21 & 0.00 & 0.00 & 5.90 & 5.48 & 5.35 \\
\hline 35 & $6 \mathrm{OCH}_{2} \mathrm{CONH}_{2}$ & 0.49 & 90.82 & 0.00 & 0.00 & 5.70 & 5.85 & 5.88 \\
\hline $36^{\mathrm{b}}$ & - & 0.46 & 37.91 & 0.00 & 0.00 & 5.50 & 5.01 & - \\
\hline 37 & - & 0.46 & 41.82 & 0.00 & 0.00 & 5.40 & 5.07 & 5.02 \\
\hline 38 & $\begin{array}{l}\text { 6-OMe-pyrid-5- } \\
\text { yl }\end{array}$ & 0.42 & 50.80 & 0.00 & 0.00 & 4.80 & 5.05 & 5.04 \\
\hline $39^{\mathrm{b}}$ & - & 0.48 & 27.05 & 0.00 & 0.00 & 4.90 & 4.91 & - \\
\hline 40 & 2,5-Furanyl & 0.50 & 41.82 & 0.00 & 0.00 & 4.90 & 5.20 & 5.23 \\
\hline $41^{c}$ & 2,5-Thienyl & 0.50 & 28.68 & 0.00 & 0.00 & 4.10 & 5.02 & - \\
\hline 42 & 2,4-Thienyl & 0.50 & 28.68 & 0.00 & 0.00 & 4.50 & 5.02 & 5.05 \\
\hline
\end{tabular}

${ }^{\mathrm{a}}$ Taken from [1]. ${ }^{\mathrm{b}}$ Taken for test set. ${ }^{\mathrm{c}}$ Not used in the derivation of (1) as they were outlier.

The positive coefficient of indicator parameter $\mathrm{I}_{1}$ indicates that the compounds with the fused ring will have better activity than those not having the fused ring. However, the negative coefficient of parameter $\mathrm{I}_{2}$ suggests that in the biaryl ring systems, compounds having a bridge group between the two aryl rings or having the pendent ring at ortho or para position would be less active than those not having these features. Compounds having such features might experience some steric problems because of the bridge group or the pendedent aryl ring not being at meta position.

The correlation expressed by (1) seems to be highly significant, and its internal and external validation can be judged by $r_{\mathrm{cv}}^{2}$ and $r_{\text {pred }}^{2}$ values, which are 0.740 and 0.742 , respectively. These values are quite large than desired $(0.60)$ for the good predicting ability of any equation. The $r_{\mathrm{cv}}^{2}$ is calculated as follows:

$$
r_{\mathrm{cv}}^{2}=1-\left[\frac{\sum_{i}\left(y_{i, \mathrm{obsd}}-y_{i, \mathrm{pred}}\right)^{2}}{\sum_{i}\left(y_{i, \mathrm{obsd}}-y_{\mathrm{av}, \mathrm{obsd}}\right)^{2}}\right],
$$

where $y_{i, \text { obsd }}$ and $y_{i \text {,pred }}$ are the observed and predicted (from LOO) activity values of compound $i$, respectively, and $y_{\mathrm{av}, \mathrm{obsd}}$, is the average of the observed activities of all compounds used in the correlation. The correlation is supposed to be valid if $r_{\mathrm{cv}}^{2}>0.60$. From this point of view, the correlation expressed by (1) seems to be quite valid. However, the predictive ability of any correlation equation is judged by predicting the activity of the compounds in the test set using it and calculating the value of $r_{\text {pred }}^{2}$ for it which is defined as

$$
r_{\text {pred }}^{2}=1-\left[\frac{\sum_{i}\left(y_{i, \text { obsd }}-y_{i, \text { pred }}\right)^{2}}{\sum_{i}\left(y_{i, \text { obsd }}-y_{\text {av }, \text { obsd }}\right)^{2}}\right],
$$

where $y_{\mathrm{av}, \mathrm{obsd}}$ and $y_{i, \text { pred }}$ refer to the observed and predicted activity of compound $i$ in the test set and $y_{\mathrm{av}, \mathrm{obsd}}$ is the same as in (2). The activity values predicted from this equation for the test set compounds are given in Table 1. A comparison shows that these predicted values are in very good agreement with the corresponding observed ones. In the training set also, the calculated values are found to be in excellent agreement with the observed ones. All these observations 
TABLE 2: Some proposed compounds belonging to the series of Table 1 and their activities predicted from (1).

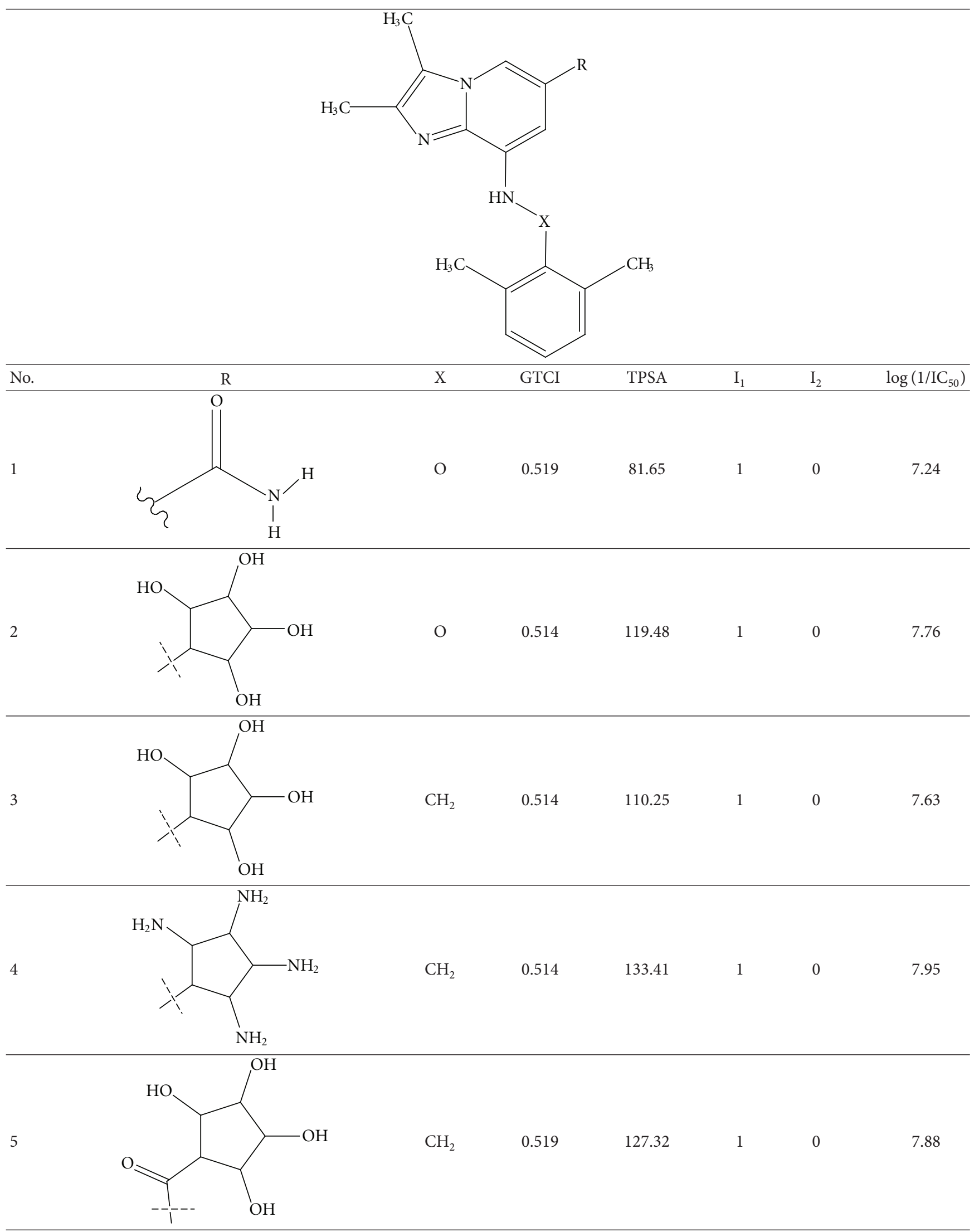


TABLE 2: Continued.

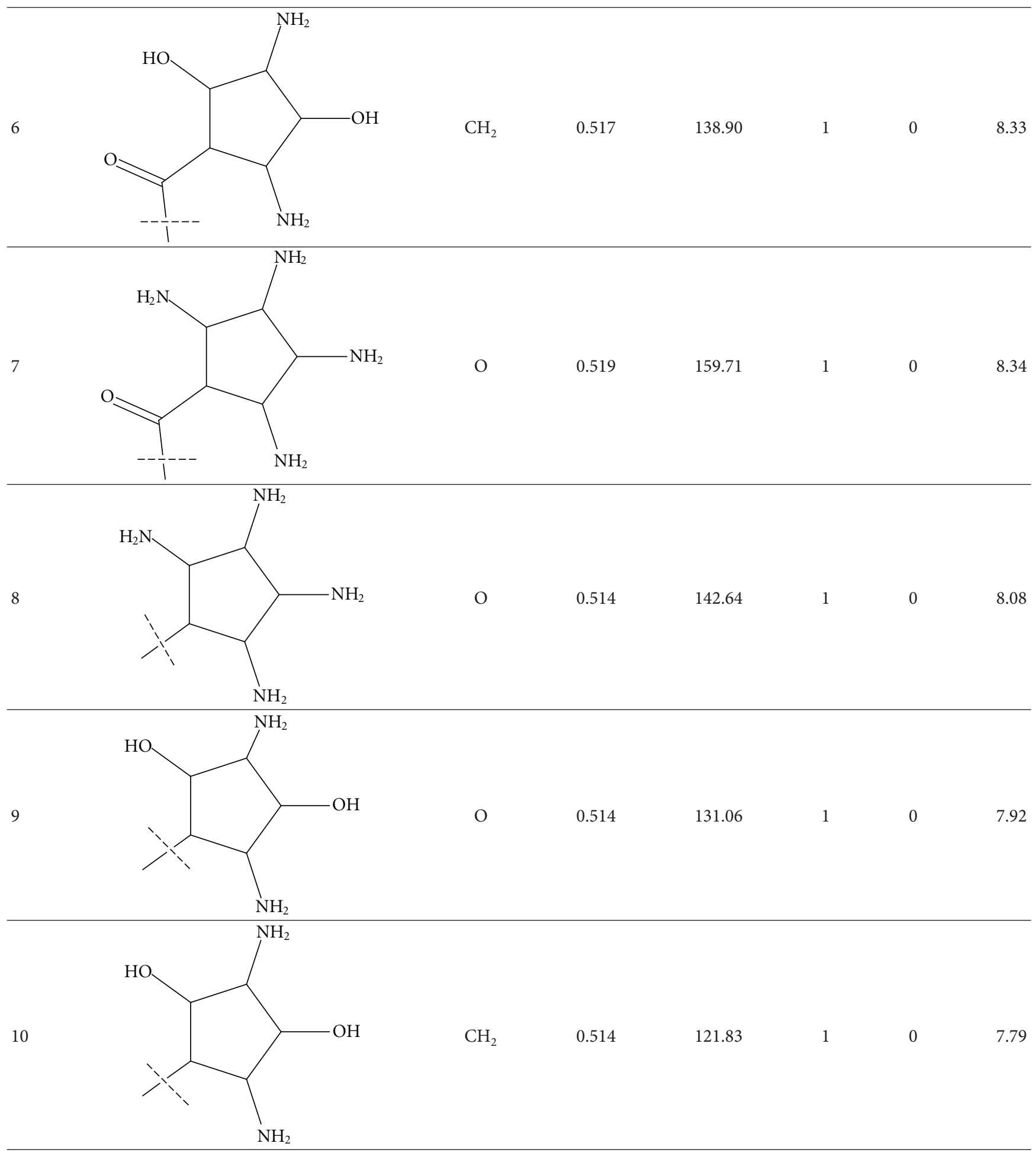

can be better visualized in the graphs drawn between the predicted and observed activities (Figure 2).

It is also to be noted that all the four parameters of (1) are statistically quite significant in the correlation. Further, these variables also reproduced the significant correlation for the test set too (see (4)), where the indicator parameter $I_{1}$ was not applicable,

$$
\begin{aligned}
\log \left(\frac{1}{\mathrm{IC}_{50}}\right)= & 4.806( \pm 3.173) \mathrm{GTCI} \\
& +0.040( \pm 0.014) \mathrm{TPSA} \\
& -0.395( \pm 0.363) \mathrm{I}_{2}+1.660( \pm 1.471), \\
n=10, \quad r= & 0.969, \quad s=0.15, \quad F_{3,6}=30.91(9.78),
\end{aligned}
$$


TABLE 3: Docking results of predicted compounds with reference to the active drugs available in the market (last four in the table).

\begin{tabular}{|c|c|c|c|c|c|c|c|}
\hline Compound & $\begin{array}{c}\text { Total interaction } \\
\text { energy }\end{array}$ & H-bond energy & No of H-bonds & H-bonds & $\begin{array}{c}\text { H-bond } \\
\text { length }(\AA)\end{array}$ & $\begin{array}{l}\text { Mole dock } \\
\text { score }\end{array}$ & $\begin{array}{c}\text { Internal energy } \\
\text { of pose }\end{array}$ \\
\hline 1 & -114.75 & -3.75 & 2 & $\begin{array}{l}\mathrm{N}(22)-\mathrm{Glu}(160) \\
\mathrm{O}(23)-\operatorname{Arg}(103)\end{array}$ & $\begin{array}{l}3.04 \\
2.72 \\
\end{array}$ & -114.75 & 6.90 \\
\hline 2 & -146.88 & -6.80 & 4 & $\begin{array}{l}\mathrm{O}(26)-\mathrm{Gln}(104) \\
\mathrm{N}(11)-\mathrm{Gly}(153) \\
\mathrm{O}(29)-\mathrm{Glu}(160) \\
\mathrm{O}(29)-\operatorname{Leu}(370)\end{array}$ & $\begin{array}{l}3.11 \\
3.07 \\
3.02 \\
3.36 \\
\end{array}$ & -147.54 & -0.66 \\
\hline 3 & -136.16 & -7.11 & 4 & $\begin{array}{l}\mathrm{O}(29)-\mathrm{G} \ln (110) \\
\mathrm{O}(29)-\mathrm{G} \ln (104) \\
\mathrm{O}(26)-\mathrm{Gly}(156) \\
\mathrm{O}(26)-\mathrm{Thr}(152)\end{array}$ & $\begin{array}{l}2.90 \\
3.04 \\
3.15 \\
3.30 \\
\end{array}$ & -148.35 & -12.19 \\
\hline 4 & -159.54 & -2.15 & 1 & N(29)-Gly(153) & 2.56 & -162.44 & -2.90 \\
\hline 5 & -153.23 & -8.40 & 4 & $\begin{array}{l}\mathrm{O}(27)-\mathrm{Gln}(110) \\
\mathrm{O}(28)-\mathrm{Gly}(107) \\
\mathrm{O}(30)-\mathrm{Leu}(346) \\
\mathrm{O}(31)-\operatorname{Thr}(350)\end{array}$ & $\begin{array}{l}3.16 \\
2.62 \\
2.60 \\
3.36 \\
\end{array}$ & -151.06 & -2.17 \\
\hline 6 & -138.98 & -6.91 & 4 & $\begin{array}{l}\mathrm{O}(27)-\mathrm{Gly}(156) \\
\mathrm{O}(27)-\operatorname{Thr}(350) \\
\mathrm{O}(28)-\mathrm{Gln}(104) \\
\mathrm{O}(30)-\mathrm{Leu}(370)\end{array}$ & $\begin{array}{l}2.35 \\
3.22 \\
2.81 \\
3.11 \\
\end{array}$ & -159.46 & -20.48 \\
\hline 7 & -146.85 & -7.71 & 2 & $\begin{array}{l}\mathrm{O}(27)-\operatorname{Thr}(350) \\
\mathrm{N}(30)-\mathrm{Glu}(160)\end{array}$ & $\begin{array}{l}2.62 \\
2.76 \\
\end{array}$ & -156.76 & -9.91 \\
\hline 8 & -159.24 & -5.35 & 1 & $\mathrm{~N}(29)-\mathrm{Gly}(153)$ & 2.60 & -146.34 & 12.90 \\
\hline 9 & -156.08 & -8.02 & 2 & $\begin{array}{l}\mathrm{O}(12)-\mathrm{Gly}(156) \\
\mathrm{O}(28)-\operatorname{Asn}(369)\end{array}$ & $\begin{array}{l}3.56 \\
2.64 \\
\end{array}$ & -147.62 & 8.48 \\
\hline 10 & -133.55 & -7.23 & 2 & $\begin{array}{l}\mathrm{O}(26)-\mathrm{G} \ln (104) \\
\mathrm{N}(27)-\mathrm{Gly}(153)\end{array}$ & $\begin{array}{l}3.07 \\
3.19 \\
\end{array}$ & -144.96 & -11.41 \\
\hline Omeprazole & -117.83 & -2.42 & 2 & $\begin{array}{l}\mathrm{O}(24)-\operatorname{Arg}(103) \\
\mathrm{O}(24)-\operatorname{Arg}(103) \\
\end{array}$ & $\begin{array}{l}2.75 \\
3.34 \\
\end{array}$ & -111.99 & 5.84 \\
\hline Lansoprazole & -121.59 & -0.10 & 2 & $\begin{array}{l}\mathrm{O}(19)-\mathrm{Gly}(156) \\
\mathrm{N}(8)-\mathrm{G} \ln (104)\end{array}$ & $\begin{array}{l}3.48 \\
3.59 \\
\end{array}$ & -115.07 & 6.521 \\
\hline Rabeprazole & -144.85 & -5.00 & 2 & $\begin{array}{l}\mathrm{O}(11)-\operatorname{Thr}(350) \\
\mathrm{N}(13)-\operatorname{Thr}(350)\end{array}$ & $\begin{array}{l}2.63 \\
3.01 \\
\end{array}$ & -131.76 & 13.09 \\
\hline Pantoprazole & -120.43 & -3.78 & 3 & $\begin{array}{l}\mathrm{O}(21)-\operatorname{Thr}(350) \\
\mathrm{N}(6)-\mathrm{G} \ln (104) \\
\mathrm{O}(11)-\mathrm{G} \ln (110)\end{array}$ & $\begin{array}{l}3.22 \\
3.10 \\
2.99 \\
\end{array}$ & -115.41 & 5.02 \\
\hline
\end{tabular}

However, certain compounds as marked with superscript " $c$ " in Table 1 were not included in the derivation of (1) as they were showing aberrant behavior. The reason of this behavior was not very clear.

In (1), we have predicted some new prospective compounds with high potency (Table 2). To predict the compounds, compounds structures were arbitrarily modified, and then the variables applicable in (1) were calculated for them and used to calculate their activity. Compounds found to possess high activity were reported. The activities of these compounds are higher than any compound in the present series (Table 1).

3.2. Docking Results. All the compounds were docked in the protein molecule (PDB id 2XZB)using Mole Grow Virtual Docker. The docked results are cited in Table 3 along with the docked results of well-known four $\mathrm{H}^{+} / \mathrm{K}^{+}$-ATPase inhibitors: omeprazole, lansoprazole, rabeprazole, and pantoprazole.
The results show that all predicted compounds have better total interaction energy and Mole Doc Score (MDS) than the marketed compounds, and compounds such as 2, 3, 5, and 6 have more number of $\mathrm{H}$-bonds with the receptor than those of the marketed compounds. The docking of compound 5 that has the highest $\mathrm{H}$-bond energy is shown as a model (Figure 3). All the compounds were also found to have hydrophobic interaction. As an example, the hydrophobic interaction of compound 5 is shown in Figure 4. Thus, all the predicted compounds seem to have good future and can be synthesized. The ADME values of these compounds were also evaluated, and their results are shown in Table 4. Table 4 shows that none of the compounds has any toxicity value, and all fulfill Lipinski's rule of 5 according to which the poor absorption and permeability of potential drugs is more likely if their molecular weight (MW) is more than $500, \log P$ is more than 5, number of $\mathrm{H}$-bond donors (HDs) is more than 5, and number of $\mathrm{H}$-bond acceptors (HAs) is more than 10. 


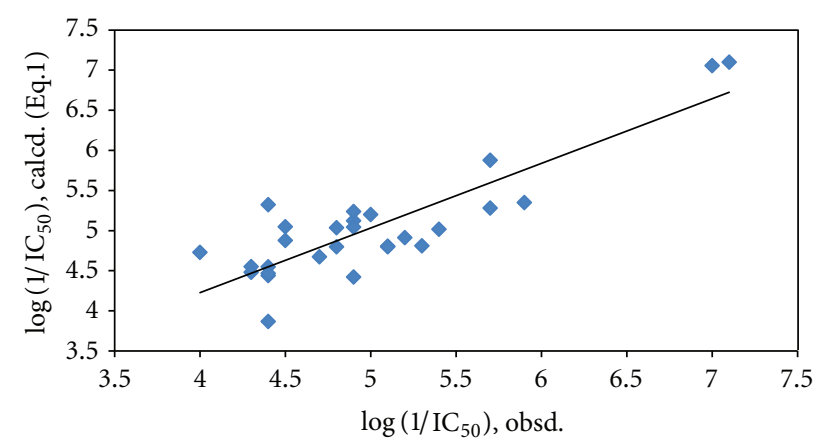

(a)

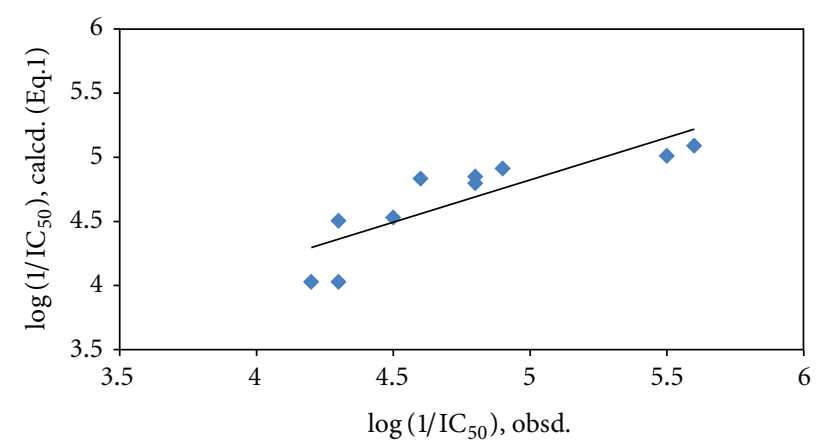

(b)

Figure 2: A plot between observed and predicted $\mathrm{H}^{+} / \mathrm{K}^{+}$-ATPase inhibition activities for compounds of Table 1: (a) for training set and (b) for test set.

TABLE 4: Data related to Lipinski rules. The last four compounds are licensed compounds given for comparision.

\begin{tabular}{lcccc}
\hline \multirow{2}{*}{ Predicted Compound in Table 2 } & \multicolumn{4}{c}{ Lipinski Parameters } \\
& MW & HA & HD & $\log P$ \\
\hline 1 & 324.377 & 5 & 2 & 2.51 \\
2 & 413.467 & 8 & 5 & 0.84 \\
3 & 411.494 & 7 & 5 & 0.49 \\
4 & 407.555 & 7 & 5 & 0.07 \\
5 & 439.504 & 8 & 5 & 0.24 \\
6 & 437.534 & 8 & 5 & 0.03 \\
7 & 437.538 & 9 & 5 & 0.16 \\
8 & 409.527 & 8 & 5 & 0.41 \\
9 & 411.497 & 8 & 5 & 0.63 \\
10 & 409.525 & 7 & 5 & 0.28 \\
Omeprazole & 383.370 & 8 & 1 & 2.18 \\
Lansoprazole & 369.361 & 7 & 1 & 3.03 \\
Rabeprazole & 339.388 & 5 & 1 & 2.56 \\
Pantoprazole & 345.416 & 5 & 1 & 2.43 \\
\hline
\end{tabular}

\section{Conclusion}

The QSAR study on a set of biaryl imidazole derivatives performed by us has suggested that the drug-receptor interaction involves the strong electronic interaction. The involvement

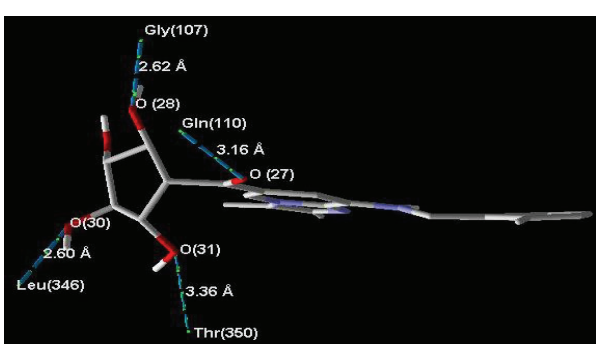

FIgURE 3: A model showing hydrogen bond interactions of predicted compound 5 (Table 2) with the amino acid residues in enzyme $\mathrm{H}^{+} / \mathrm{K}^{+}$-ATPase.

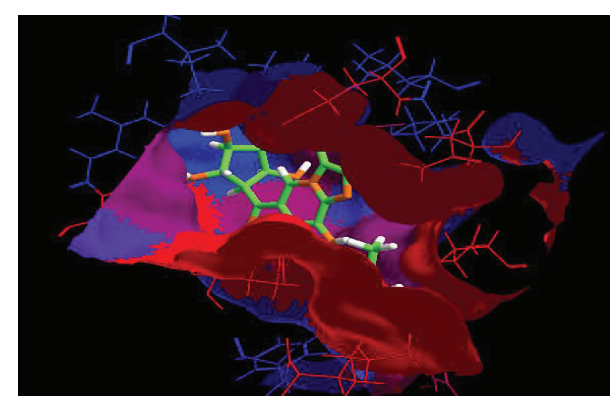

FIgURE 4: The model showing hydrophobic interactions of predicted compound 5 (Table 2) with the enzyme $\mathrm{H}^{+} / \mathrm{K}^{+}$-ATPase. The red surface shows strong hydrophobic zone and the blue one low hydrophobic zone.

of electronic interaction in $\mathrm{H}^{+} / \mathrm{K}^{+}$-ATPase inhibition has been shown by other authors also. We have, however, also found that biaryl imidazole derivatives can also undergo hydrogen bonding and hydrophobic interaction. A set of compounds that may have better activity have been predicted based on our QSAR model. By docking these compounds are shown to possess the activity even better than the marketed compounds.

\section{References}

[1] N. Garton, N. Bailey, M. Bamford et al., "Discovery of biaryl inhibitors of $\mathrm{H}^{+} / \mathrm{K}^{+}$ATPase," Bioorganic and Medicinal Chemistry Letters, vol. 20, no. 3, pp. 1049-1054, 2010.

[2] P. J. Zimmermann, W. Buhr, C. Brehm et al., "Novel indanylsubstituted imidazo $[1,2-a]$ pyridines as potent reversible inhibitors of the gastric $\mathrm{H}^{+} / \mathrm{K}^{+}$-ATPase," Bioorganic \& Medicinal Chemistry Letters, vol. 17, no. 19, pp. 5374-5378, 2007.

[3] M. R. S. Nayana, Y. N. Sekhar, H. Nandyala et al., "Insight into the structural requirements of proton pump inhibitors based on CoMFA and CoMSIA studies," Journal of Molecular Graphics and Modelling, vol. 27, no. 3, pp. 233-243, 2008.

[4] J. V. Esplugues, "A pharmacological approach to gastric acid inhibition," Drugs, vol. 65, no. 1, pp. 7-12, 2005.

[5] W. Beil, I. Hackbarth, and K. F. Sewing, "Mechanism of gastric antisecretory effect of SCH 28080," British Journal of Pharmacology, vol. 88, no. 1, pp. 19-23, 1986.

[6] B. Wallmark, C. Briving, J. Fryklund, K. Munson, R. Jackson, and J. Mendlein, "Inhibition of gastric $\mathrm{H}^{+}, \mathrm{K}^{+}$-ATPase and acid secretion by $\mathrm{SCH}, 28080$, a substituted pyridyl(1, 
2a)imidazole," The Journal of Biological Chemistry, vol. 262, no. 5, pp. 2077-2084, 1987.

[7] A. W. Herling and K. Weidmann, "Gastric proton pump inhibitors," in Burger's Medicinal Chemistry and Drug Discovery, M. E. Wolff, Ed., vol. 2, pp. 122-134, John Wiley \& Sons, New York, NY, USA, 5th edition, 1996.

[8] J. Mossner and K. Caca, "Developments in the inhibition of gastric acid secretion," European Journal of Clinical Investigation, vol. 35, no. 8, pp. 469-475, 2005.

[9] K. Andersson and E. Carlsson, "Potassium-competitive acid blockade: a new therapeutic strategy in acid-related diseases," Pharmacology and Therapeutics, vol. 108, no. 3, pp. 294-307, 2005.

[10] P. J. Zimmermann, C. Brehm, W. Buhr, A. M. Palmer, J. Volz, and W. A. Simon, "Novel imidazo[1,2-a]pyrazine derivatives as potent reversible inhibitors of the gastric $\mathrm{H}^{+} / \mathrm{K}^{+}$-ATPase," Bioorganic and Medicinal Chemistry, vol. 16, no. 1, pp. 536-541, 2008.

[11] P. Lindberg, A. Brandstrom, B. Wallmark, H. Mattsson, L. Rikner, and K. J. Hoffmann, "Omeprazole: the first proton pump inhibitor," Medicinal Research Reviews, vol. 10, no. 1, pp. 1-54, 1990.

[12] T. N. Ojha, R. C. Sharma, and P. Singh, "Quantitative structure-activity relationship study of 2-[(2-benzimidazolylsulphinyl)methyl]-aniline inhibitors of $\mathrm{H}^{+} / \mathrm{K}^{+}$-Aptase," Drug Design and Delivery, vol. 6, no. 4, pp. 289-296, 1990.

[13] P. Singh, R. C. Sharma, and T. N. Ojha, "Qunatative structure activity relationship studies of inhibitors of $\left(\mathrm{H}^{+} / \mathrm{K}^{+}\right)$-Aptase," Drug Design and Delivery, vol. 7, no. 2, pp. 131-138, 1991.

[14] T. N. Ojha, P. Singh, and R. C. Sharma, "Structure-activity relationship studies of 4-substituted-2-guanidinothiazoles: reversible inhibitors of gastric $\left(\mathrm{H}^{+} / \mathrm{K}^{+}\right)$-ATPase," Indian Journal of Biochemistry and Biophysics, vol. 30, no. 4, pp. 239-243, 1993.

[15] E. G. Borges and Y. Takahata, "QSAR study of anti-ulcer compounds using calculated parameters," Journal of Molecular Structure, vol. 539, no. 1-3, pp. 245-251, 2001.

[16] E. G. Borges and Y. Takahata, "The 4-indolyl-2-guanidinothiazoles QSAR study of anti-ulcer activity using quantum descriptors," Journal of Molecular Structure, vol. 580, no. 1-3, pp. 263-270, 2002.

[17] P. Sharma, S. Singh, T. I. Siddiqui et al., " $\alpha$-Amino acid derivatives as proton pump inhibitors and potent anti-ulcer agents," European Journal of Medicinal Chemistry, vol. 42, no. 3, pp. 386-393, 2007.

[18] M. R. S. Nayana, Y. N. Sekhar, H. Nandyala et al., "Insight into the structural requirements of proton pump inhibitors based on CoMFA and CoMSIA studies," Journal of Molecular Graphics and Modelling, vol. 27, no. 3, pp. 233-243, 2008.

[19] http://www.vcclab.org/lab/edragon/.

[20] http://apodvision.com/apod/apod.pl. 

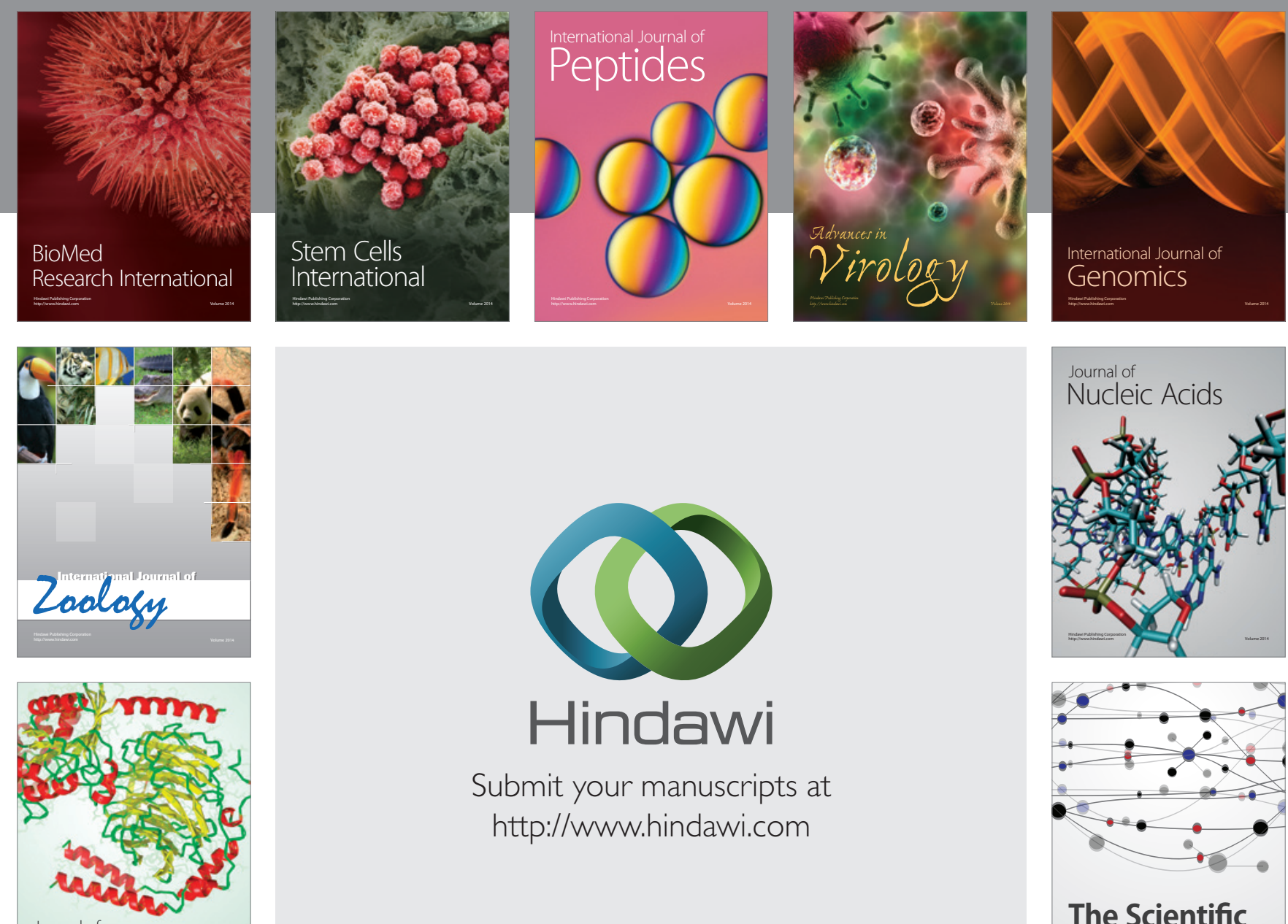

Submit your manuscripts at

http://www.hindawi.com

Journal of
Signal Transduction
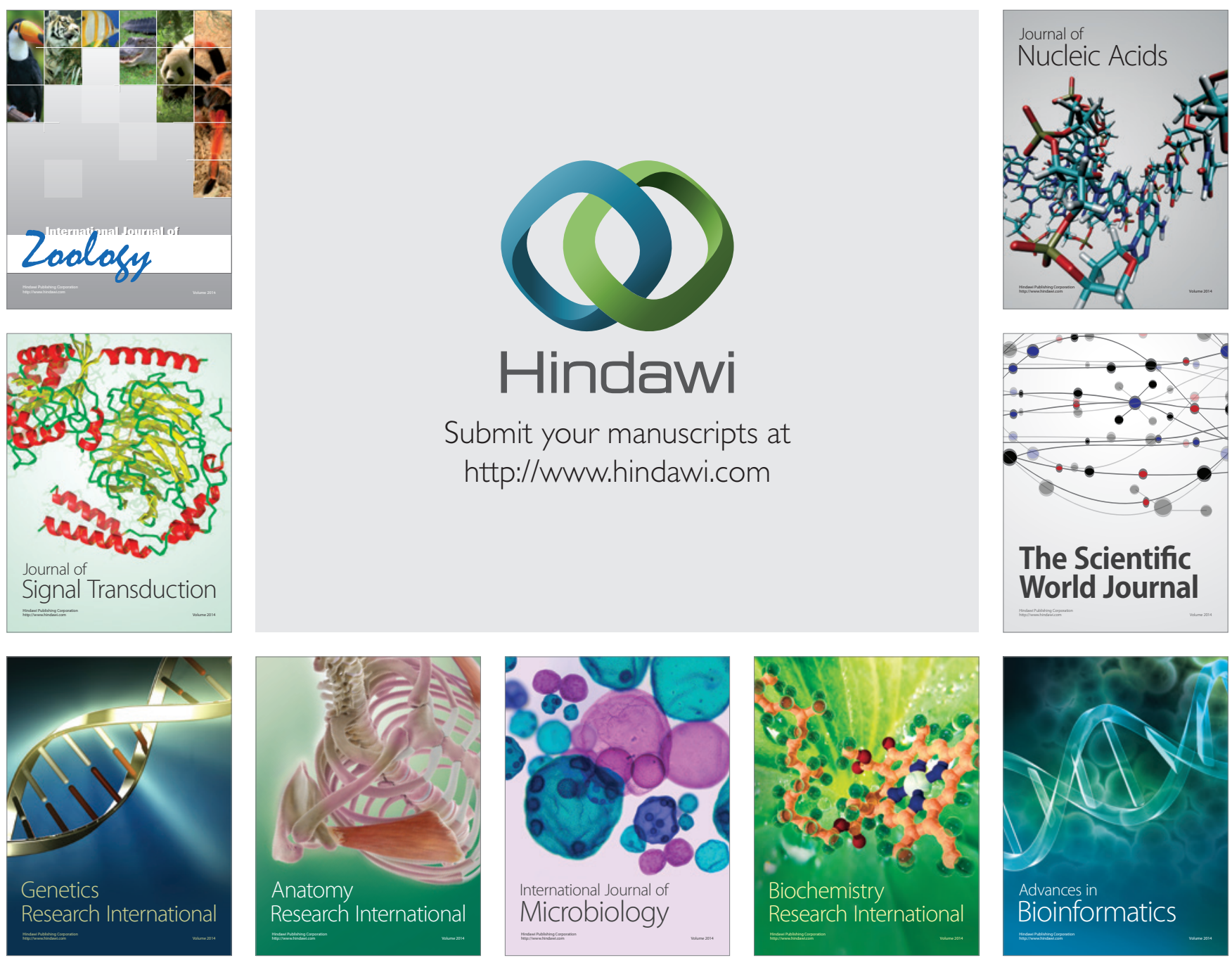

The Scientific World Journal
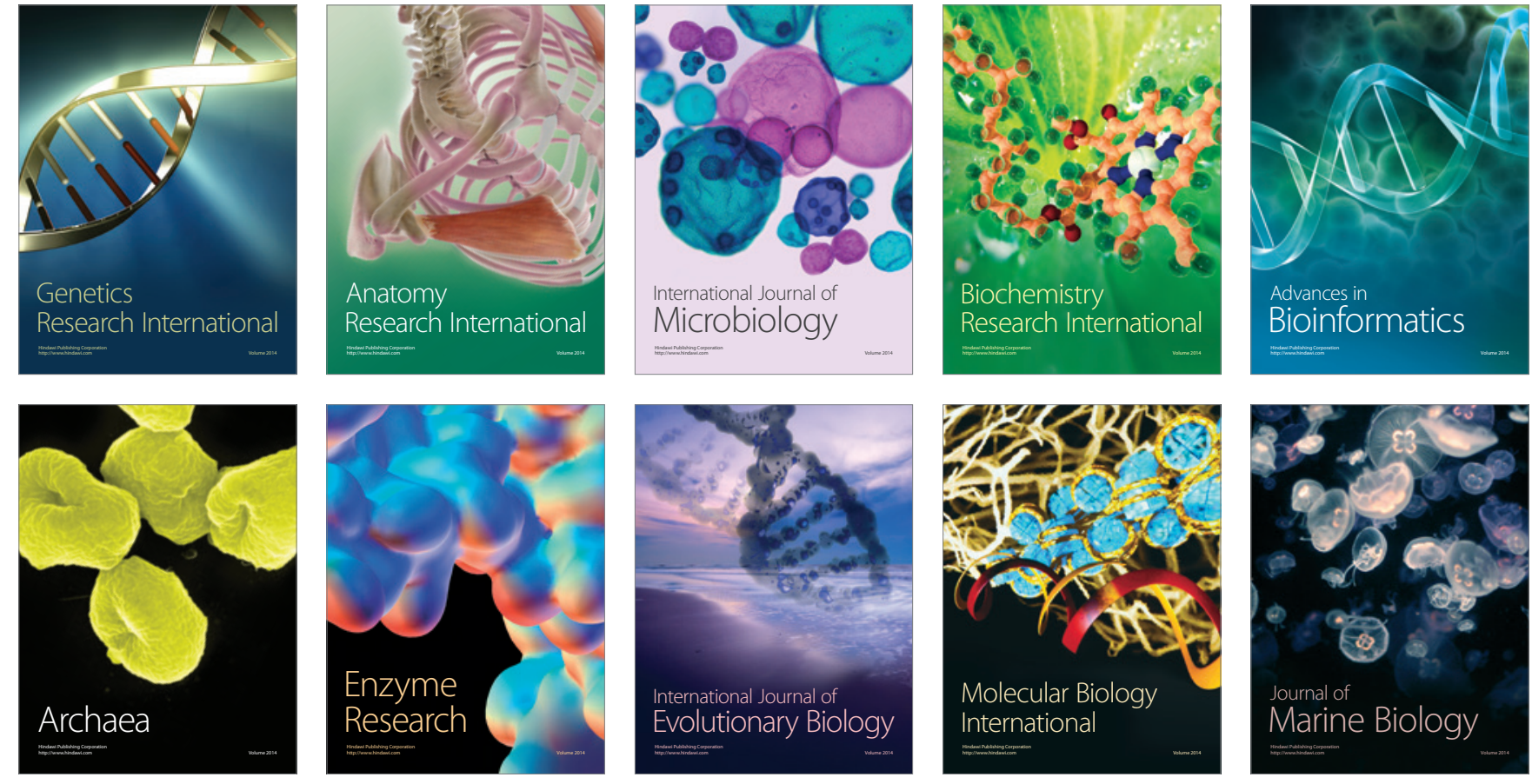